\title{
The role of the basic state in the ENSO- monsoon relationship and implications for predictability
}

Article

Published Version

Turner, A.G., Inness, P.M. and Slingo, J.M. (2005) The role of the basic state in the ENSO-monsoon relationship and implications for predictability. Quarterly Journal of the Royal Meteorological Society, 131 (607). pp. 781-804. ISSN 1477870X doi: https://doi.org/10.1256/qj.04.70 Available at https://centaur.reading.ac.uk/1051/

It is advisable to refer to the publisher's version if you intend to cite from the work. See Guidance on citing.

Published version at: http://dx.doi.org/10.1256/aj. 04.70

To link to this article DOI: http://dx.doi.org/10.1256/qj.04.70

Publisher: Royal Meteorological Society

All outputs in CentAUR are protected by Intellectual Property Rights law, including copyright law. Copyright and IPR is retained by the creators or other copyright holders. Terms and conditions for use of this material are defined in the End User Agreement.

www.reading.ac.uk/centaur 
Central Archive at the University of Reading

Reading's research outputs online 


\title{
The role of the basic state in the ENSO-monsoon relationship and implications for predictability
}

\author{
By A. G. TURNER*, P. M. INNESS and J. M. SLINGO \\ Centre for Global Atmospheric Modelling, University of Reading, UK
}

(Received 12 May 2004; revised 8 November 2004)

\section{SUMMARY}

The impact of systematic model errors on a coupled simulation of the Asian summer monsoon and its interannual variability is studied. Although the mean monsoon climate is reasonably well captured, systematic errors in the equatorial Pacific mean that the monsoon-ENSO teleconnection is rather poorly represented in the general-circulation model. A system of ocean-surface heat flux adjustments is implemented in the tropical Pacific and Indian Oceans in order to reduce the systematic biases. In this version of the general-circulation model, the monsoon-ENSO teleconnection is better simulated, particularly the lag-lead relationships in which weak monsoons precede the peak of El Niño. In part this is related to changes in the characteristics of El Niño, which has a more realistic evolution in its developing phase. A stronger ENSO amplitude in the new model version also feeds back to further strengthen the teleconnection. These results have important implications for the use of coupled models for seasonal prediction of systems such as the monsoon, and suggest that some form of flux correction may have significant benefits where model systematic error compromises important teleconnections and modes of interannual variability.

KEYWORDS: Interannual variability Seasonal forecasting Systematic errors

\section{INTRODUCTION}

The Asian summer monsoon affects the lives of more than 2 billion people in India, China and the rest of south-east Asia, mainly through the reliance of agriculture on the timing, duration, and strength of the monsoon season. Sophisticated generalcirculation models (GCMs) are increasingly being used to predict these details of the monsoon season, potentially allowing crop sowing to be more efficiently timed or contingency plans to be made in the event of flood or drought seasons. However, the limited level of skill in dynamical forecasts for seasonal prediction means that they cannot be exclusively relied upon, and therefore empirical methods are still employed, such as by the India Meteorological Department (Rajeevan et al. 2004).

The state of equatorial Pacific sea surface temperatures (SSTs) has long been regarded as an important predictor of the monsoon, with studies such as Charney and Shukla (1981) and Palmer (1994) suggesting that the low-frequency Pacific SST variations predispose the monsoon to either a strong or weak season. Ju and Slingo (1995) also noted that the causal relationship between the monsoon and ENSO was central to seasonal prediction. Thus, GCMs used for seasonal prediction should be

* Corresponding author: NCAS CGAM, Department of Meteorology, University of Reading, PO Box 243, Earley Gate, Reading RG6 6BB, UK. e-mail: a.g.turner@ rdg.ac.uk

(c) Royal Meteorological Society, 2005. 
able to simulate the teleconnection between equatorial Pacific SST variations and the monsoon. This teleconnection depends on the Walker circulation to deliver the Pacific SST signal to the Indian Ocean sector (see e.g. Shukla and Paolino 1983; Webster and Yang 1992). Further, Meehl and Arblaster (2002a,b) found that the monsoon and ENSO phenomena were part of a wider system termed the tropospheric biennial oscillation (TBO). This TBO involves a transition period in northern spring to the summer monsoon season such that a strong monsoon in the previous year is often followed by a relatively weak one in the following year. The transition period is heavily reliant on coupled landatmosphere-ocean processes, with Indo-Pacific Ocean SST anomalies being dominant. Meehl et al. (2003) further stress the importance of SST forcing, whilst highlighting the fundamental role of the Walker circulation in linking the anomalous atmospheric conditions and ocean dynamics across the Indo-Pacific sectors.

Therefore, a GCM should not only be able to simulate the correct Pacific SST variability, but must also produce a correct simulation of the mean Walker circulation in order to reproduce the correct monsoon response to Pacific SST variations. Indeed, Sperber and Palmer (1996) found that GCMs which generate mean climatologies most closely in agreement with observations were more likely to simulate the correct interannual variability of tropical precipitation. So a poorly represented mean state may impact on global teleconnections, and consequently limit the prospects for seasonal monsoon prediction.

The purpose of this study is to examine the role of basic state errors on the simulation of the monsoon-ENSO teleconnection in the Met Office Hadley Centre coupled model HadCM3. A system of limited-area flux adjustments will be used to reduce the systematic biases of the GCM in the equatorial Pacific and Indian Ocean basins. The impact of these changes on the simulation of ENSO variability and the teleconnection between ENSO and the monsoon will be assessed. Section 2 will describe the model formulation, datasets used, and experimental design. Section 3 will look at the impact of tropical Pacific SST errors on the basic state of the model and associated mean circulation, first noting the systematic errors to the mean summer climate, and then noting any improvements following flux adjustments. The impact of basic state changes on monsoon variability will be documented in section 4 and changes to the ENSO behaviour of the model will be described in section 5. The monsoon-ENSO teleconnection will be considered in section 6 , followed by conclusions in section 7 .

\section{MODEL, OBSERVED DATASETS AND EXPERIMENTAL DESIGN}

\section{(a) The HadCM3 coupled model}

HadCM3 is a fully coupled GCM combining comprehensive atmosphere and ocean components. As a state-of-the-art coupled model, it was widely used to provide climate change scenarios for the Intergovernmental Panel on Climate Change Third Assessment Report (IPCC 2001). The simulated climate of HadCM3 is stable so that multi-century integrations can be performed with no significant climate drift, as noted by Johns $e t$ al. (2003).

Pope et al. (2000) provide a detailed description of the atmospheric component, HadAM3. The atmospheric component of HadCM3 has a regular grid of $3.75^{\circ}$ longitude by $2.5^{\circ}$ latitude, approximately comparable to a T42 spectral resolution. The default vertical resolution is 19 levels, but 30 levels are used in this study, halving the layer thickness in the mid-troposphere to $50 \mathrm{mb}$. This produces more realistic representation of the intraseasonal behaviour of tropical convection such as the Madden-Julian oscillation (MJO), as found by Inness et al. (2001). 
The oceanic component has a uniform resolution of $1.25^{\circ}$ by $1.25^{\circ}$ with 20 levels in the vertical. Gordon et al. (2000) describe the design of the ocean component in detail. The ocean and atmosphere components of HadCM3 are coupled once per day. The L30 version of HadCM3 was integrated as a control run for 100 years, after a 10-year spinup period with initial conditions taken from an L19 integration of HadCM3. The L30 version of the model is also stable and its climatology is similar to that of the standard L19 version.

\section{(b) Observed datasets}

Various observationally based datasets have been used to evaluate the model's performance, to identify the key systematic errors and to provide a description of monsoon variability and its teleconnections with El Niño. The recently completed European Centre for Medium-Range Weather Forecasts (ECMWF) reanalysis dataset (ERA-40), covering 1958-97, has provided the principal source of data for evaluating the model and describing monsoon variability. ERA-40 is based on a T159 L60 version of the ECMWF Integrated Forecasting System, incorporating externally produced analyses of SST from the Met Office (pre-1981) and the US National Centers for Environmental Prediction (post-1981). Since precipitation is regarded as one of the least reliable fields, quantitatively, from reanalyses, the Climate Prediction Center Merged Analysis of Precipitation (CMAP) dataset (Xie and Arkin 1997) is also used to assess the model's mean climate. However, to study monsoon variability and its teleconnections with ENSO, ERA-40 precipitation is used since it provides a longer dataset. For consistency with the dynamical fields, sea surface temperatures from ERA-40 have been used throughout this study, for model evaluation and for describing observed monsoon variability.

In addition, the All-India Rainfall (AIR) dataset (Parthasarathy et al. 1994)*, based on rain-gauge data, has been used to provide another measure of monsoon variability. Data on oceanic temperature structure have been obtained from the Levitus dataset (Levitus and Boyer 1994).

\section{(c) Design of the flux-adjusted experiment}

The role of the basic state in the simulation of the Asian summer monsoon and its variability is studied using a flux-adjusted integration of HadCM3 to correct errors in the mean tropical climate. The flux adjustment procedure was first carried out by Inness et al. (2003), originally to investigate the sensitivity of MJO simulation to basic state errors in low-level zonal wind and SST, crucial components of the proposed coupled mechanism for the MJO. The coupled model on 30 levels is first run for 20 years, with the SSTs from $10^{\circ} \mathrm{S}-10^{\circ} \mathrm{N}$ in the Indian and Pacific Oceans being relaxed back to climatology on a 14-day time-scale $†$.

Between $5^{\circ} \mathrm{S}$ and $5^{\circ} \mathrm{N}$, the relaxation is applied in full, but is ramped down to zero at $\pm 10^{\circ}$, such that SSTs outside of this band are freely evolving. The anomalous heat fluxes are saved and averaged to generate a mean annual cycle of flux adjustments. No adjustment is made to the wind stress. A second model integration for 100 years (HadCM3FA) then applies the flux adjustment cycle at the ocean surface. Daily flux adjustment values are interpolated linearly between monthly mean values. This strategy constrains the mean equatorial SSTs in the GCM close to observed values, whilst still allowing variability of SST about the adjusted mean state.

\footnotetext{
* Obtained in 2003 from http://www.tropmet.res.in

$\dagger$ Adjustments are made to this narrow latitudinal region because we wish to have as small an impact as possible on the basic state of the GCM, whilst fixing the coupled systematic error in the equatorial region, as explained by Inness et al. (2003).
} 


\section{THE INFLUENCE OF TROPICAL PACIFIC SST ERRORS ON THE GCM BASIC STATE}

To determine the influence of the basic state on the simulation of the monsoonENSO teleconnections, the mean climate of the model first needs to be assessed. Inness et al. (2003) documented the major tropical systematic errors in HadCM3 for the October-April season, and to a large extent, their findings are also true for the boreal summer (June-September, JJAS) season. Figure 1 shows the mean surface temperature, $850 \mathrm{mb}$ winds and precipitation for HadCM3 in JJAS, together with differences from ERA-40 and CMAP. Typical of many coupled models, the central equatorial Pacific is too cold by about $3 \mathrm{~K}$, with the waters around the Maritime Continent being too warm. Across the equatorial Pacific, the easterly trade winds are too strong by about $5 \mathrm{~m} \mathrm{~s}^{-1}$, and HadCM3 also develops excessive precipitation around the Maritime Continent. Inness et al. (2003) describe these low-level wind, precipitation, and SST errors in terms of a coupled mechanism whereby the strong easterly winds confine the warm pool to the Maritime Continent. Convection is also confined to this region and is too strong, driving a strong Walker circulation with strong trades. In the central and east Pacific the anomalous easterlies lead to upwelling of cold water via Ekman divergence. The zonal SST gradient across the Pacific is thus enhanced, further reinforcing the excessive trade winds in HadCM3.

Over the Indian Ocean sector, the main features of the monsoon flow are reasonably well simulated by HadCM3. The strength and position of the low-level monsoon jet are captured, although the westerly flow across India and the southern Bay of Bengal is rather strong. The cross-equatorial component of the flow extends too far eastward rather than being confined to the Somali jet, possibly related to the resolution of the atmospheric component of HadCM3. The main precipitation error in the Indian sector is a large dry bias just south of the equator in the centre of the Indian Ocean, arguably related to the systematic errors over the Maritime Continent (Neale and Slingo 2003). Over India itself, rainfall totals are slightly too high on the west coast and somewhat deficient in the north-west. HadCM3 thus features several indicators of a bias towards a strong monsoon in its mean summer climate, such as the enhanced Pacific trade winds and stronger monsoon westerlies (see e.g. Webster et al. 1998). So the model, although simulating the basic monsoon behaviour quite well, has some systematic errors, particularly in the Pacific sector, which may impact on the simulation of monsoon interannual variability. This will be investigated in section 4 .

Figure 2(a) shows the annual mean of the ocean heat flux adjustments applied to HadCM3FA to correct the model systematic errors in the Indo-Pacific sector. Large positive fluxes go into the ocean in the central equatorial cold tongue (up to $186 \mathrm{~W} \mathrm{~m}^{-2}$ at $120^{\circ} \mathrm{W}$ ). Adjustments are much smaller in the Indian Ocean and west Pacific warm pool, no greater than $\pm 30 \mathrm{~W} \mathrm{~m}^{-2}$. The amplitude of the annual cycle of flux adjustments (Fig. 2(b)) is generally small in this region, except in the upwelling region off the African coast. Figure 3(d) shows the impact of these flux adjustments on the JJAS SST climatology of HadCM3FA. As intended, the central equatorial Pacific has warmed by up to $2.5 \mathrm{~K}$ and SSTs around the Maritime Continent have been reduced by up to $1.5 \mathrm{~K}$. The overall effect is thus to extend the west Pacific warm pool eastwards towards the Date Line (Fig. 3(a)) and to provide a better simulation of the zonal SST gradient.

The improved zonal temperature gradient across the west Pacific has reduced the anomalously strong easterly trades, whilst over the Indian Ocean the zonal component of flow on the equator is more easterly. The monsoon flow across the Arabian Sea and the Indian peninsula is reduced, and there is an overall improvement in the simulation of the low-level winds. Comparison of the precipitation changes (Figs. 1(f) and 3(f)) 

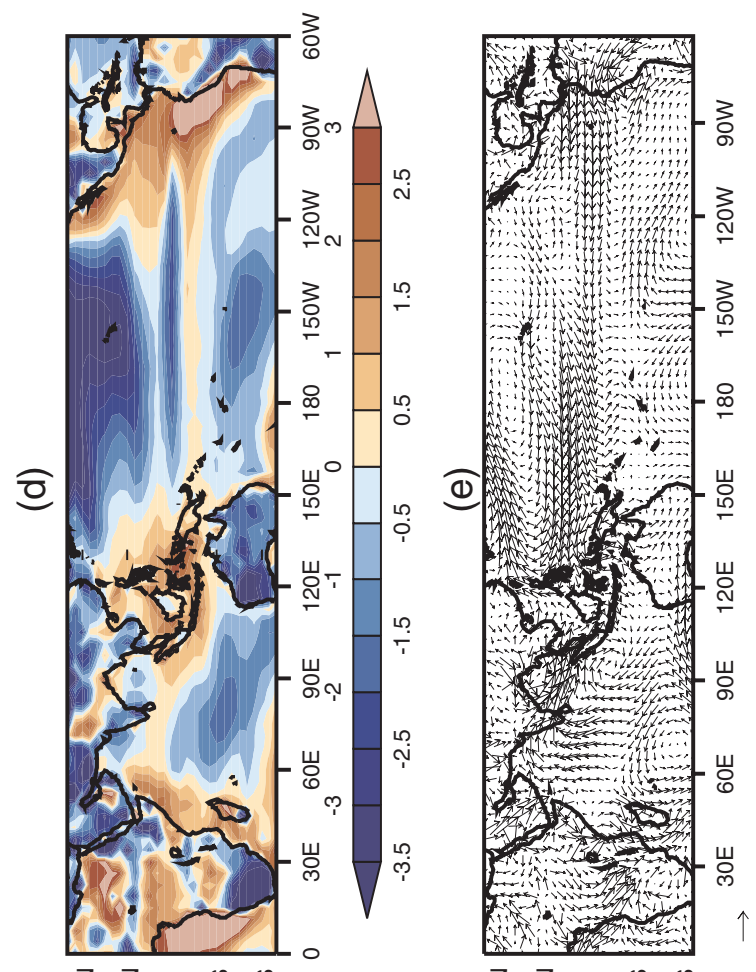

$\frac{3}{5}$
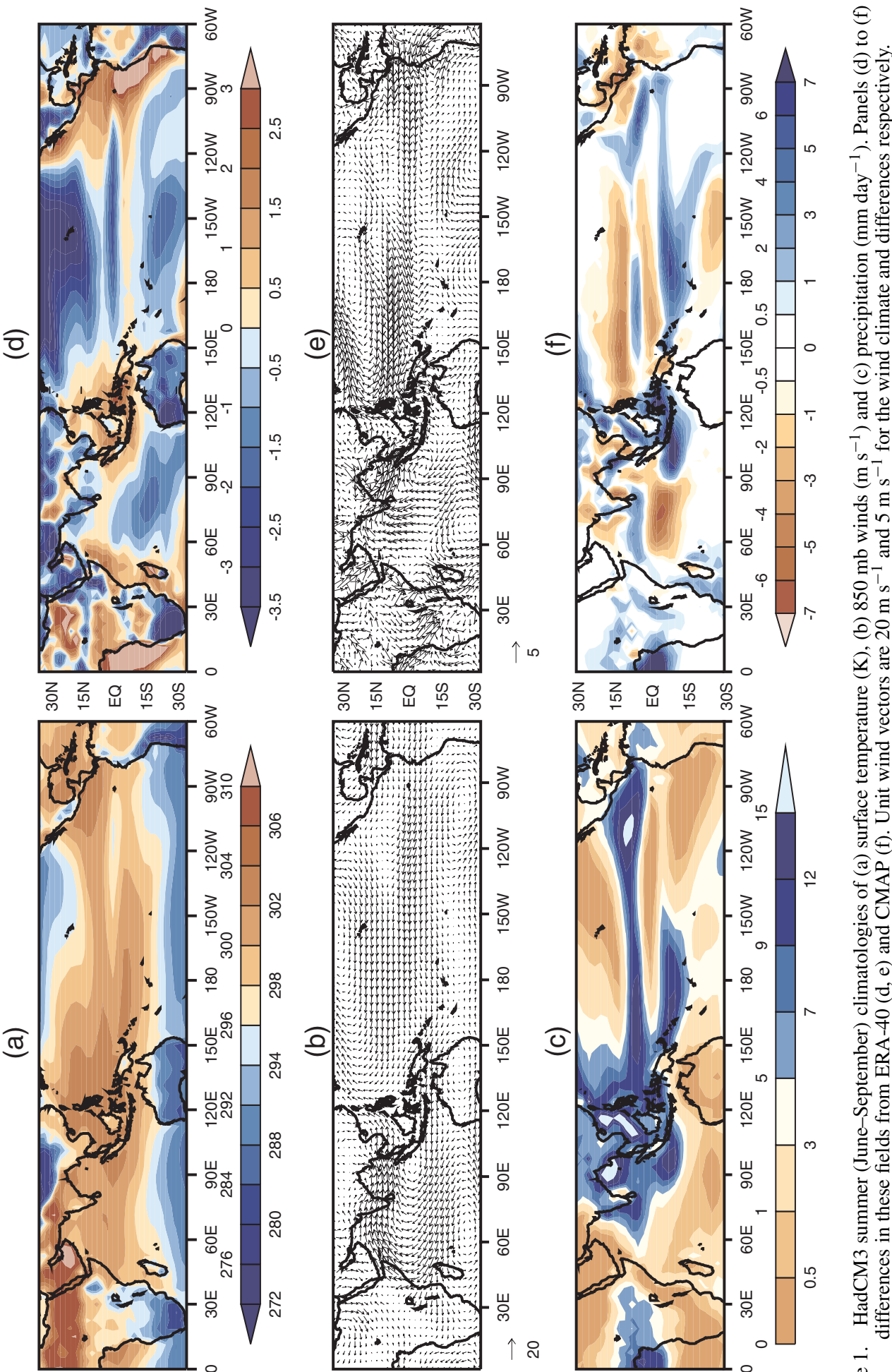

预造

흘

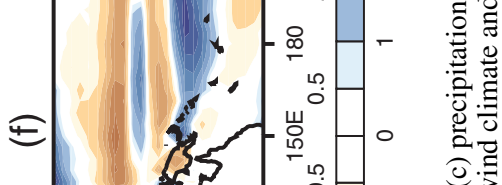

$\Phi$
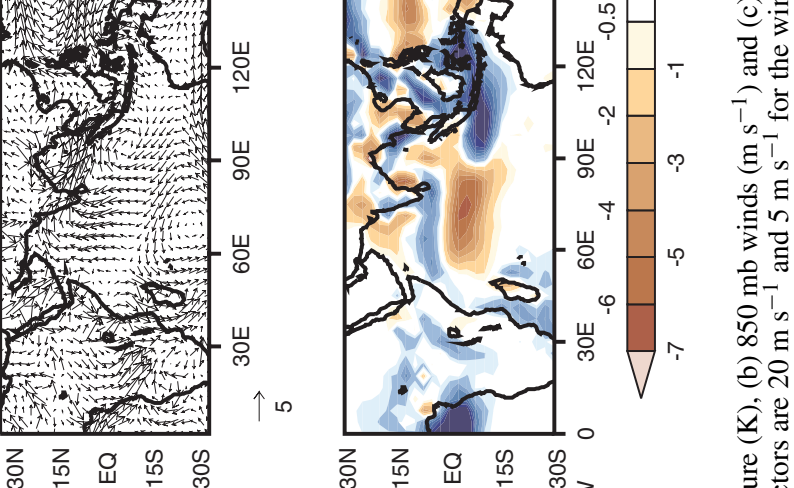

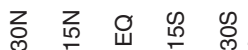

产
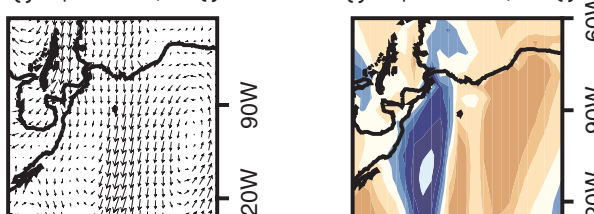

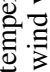

记.

莺

草

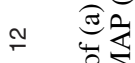

$\circ \sum_{0}$

응믐

응 ส

节

웡

बै

บิ

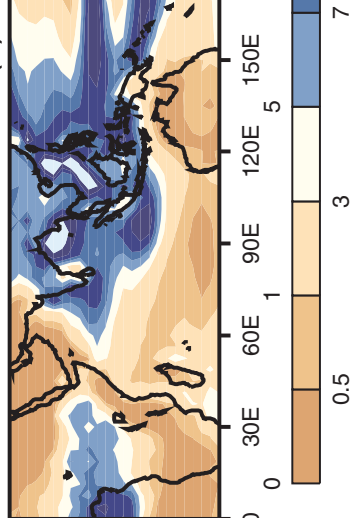

这

吾㐘

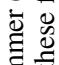

寻

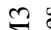

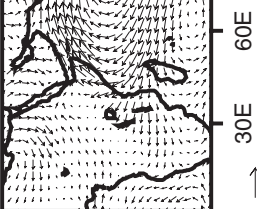

$\uparrow$ จ

焉 
(a)

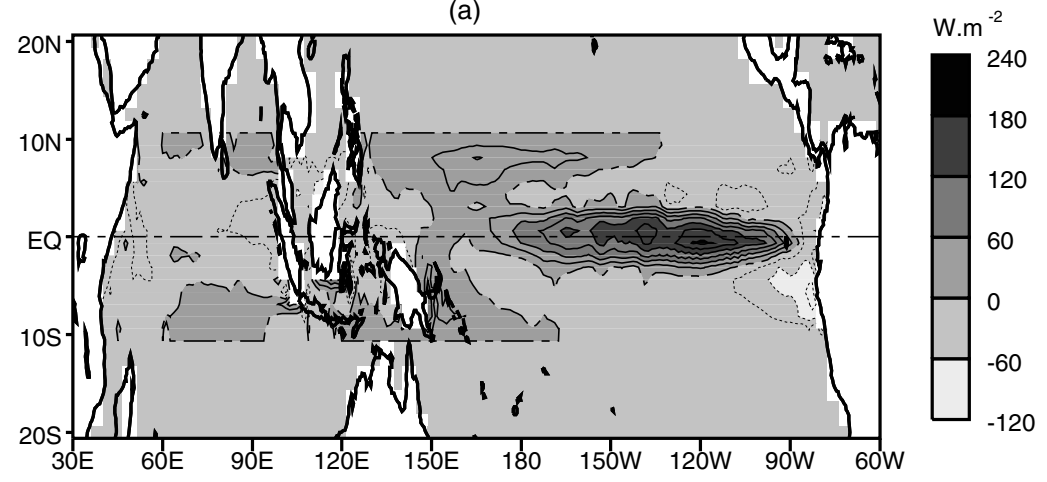

(b)

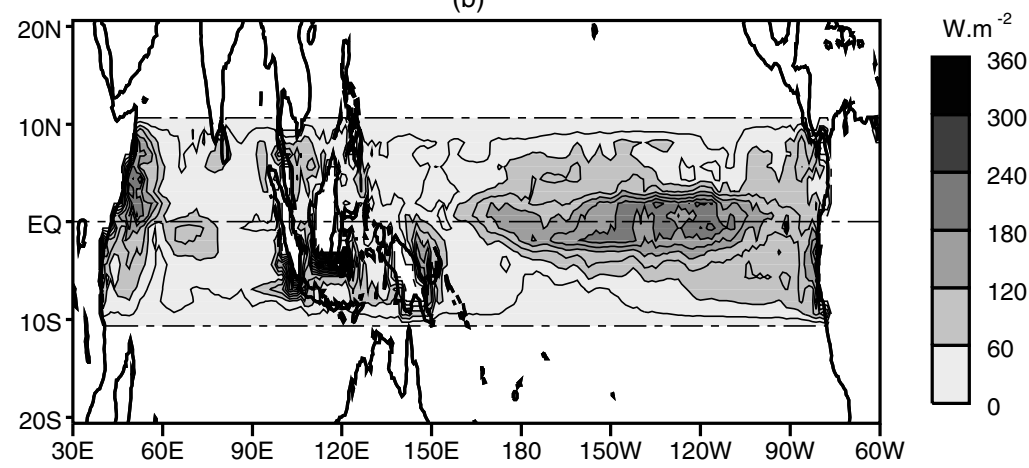

Figure 2. The (a) annual mean and (b) amplitude of seasonal cycle of flux adjustments applied to HadCM3 to generate HadCM3FA, taken from Inness et al. (2003).

shows that the flux adjustments force precipitation changes which are opposite in sign to the systematic errors in HadCM3 throughout most of the Indian Ocean and Pacific sectors. In particular, the excessive precipitation around the Maritime Continent has been reduced, with more rain occurring along the west Pacific intertropical convergence zone, and also just south of the equator in the Indian Ocean. Over India itself, the west coast is drier in HadCM3FA. However, the north-west of India, which was already too dry in HadCM3, is now even drier in HadCM3FA.

These precipitation and wind changes over the tropical Pacific in both winter (see Inness et al. 2003) and summer, suggest that in HadCM3FA the Walker cells are more realistically positioned, with convection and ascent occurring some $30^{\circ}$ further east in the Pacific Ocean. This reflects the reduced zonal temperature gradient and less confined warm pool, an important point which will be discussed in section 6 . Although the overall thermocline depth has not changed (not shown), the thermocline is more intense in HadCM3FA. As a simple measure, Meehl et al. (2001) used the $16-22{ }^{\circ} \mathrm{C}$ thickness at $155^{\circ} \mathrm{W}$. The average of this thickness over the integrations is $80 \mathrm{~m}$ in HadCM3 but $68 \mathrm{~m}$ in HadCM3FA. The flux-adjusted value is clearly more realistic when compared to $41 \mathrm{~m}$ in the Levitus ocean temperature dataset.

To look at the timing and extent of the monsoon in each of the datasets, a useful method is to consider the evolution of lower- and upper-level winds in the monsoon region. Figure 4 shows the mean annual cycle of upper (200 mb) and lower $(850 \mathrm{mb})$ tropospheric winds (after Webster and Yang 1992). The region chosen for study $\left(5-20^{\circ} \mathrm{N}, 40-110^{\circ} \mathrm{E}\right)$ covers India, Saudi Arabia, Thailand and the western part 

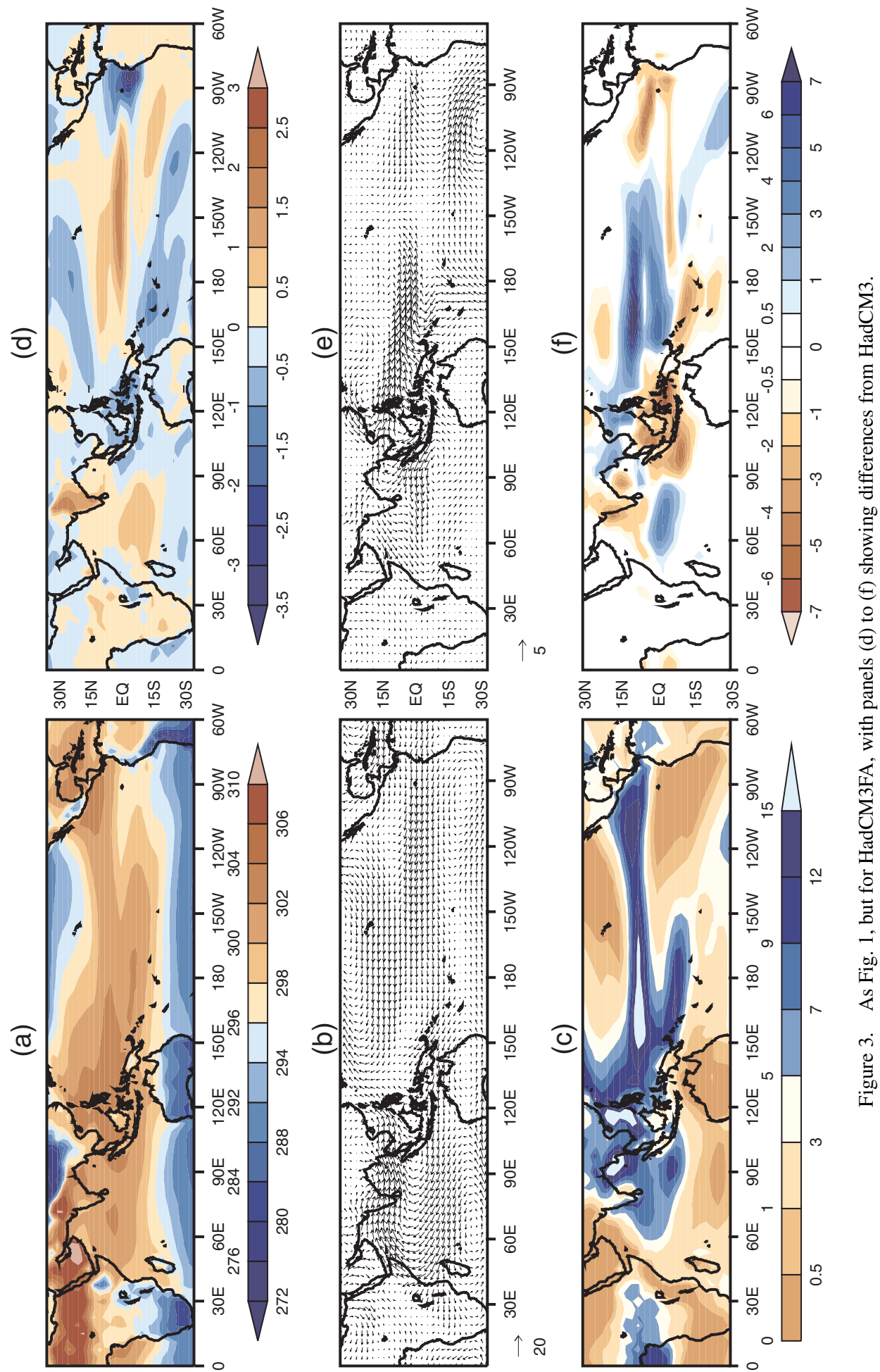


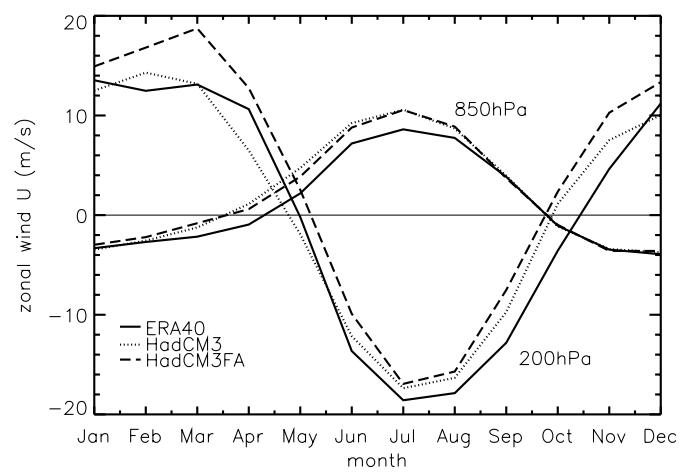

Figure 4. Annual cycle of 850 and $200 \mathrm{mb}$ winds in ERA-40, HadCM3 and HadCM3FA in the region 5-20 N, $40-110^{\circ} \mathrm{E}$.

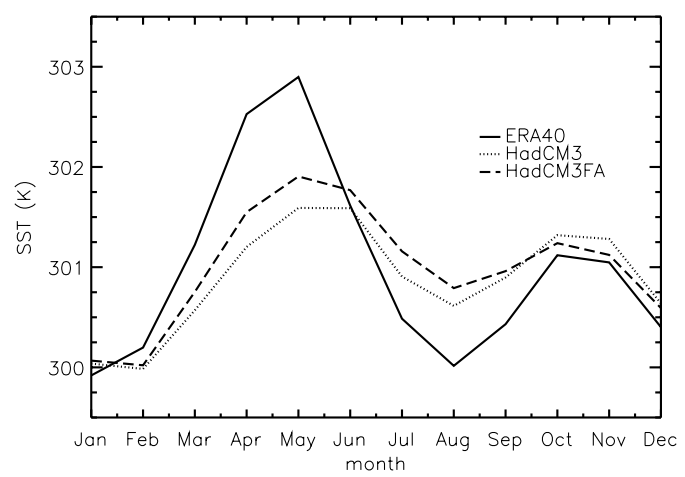

Figure 5. Annual cycle of sea surface temperatures in ERA-40, HadCM3 and HadCM3FA over the Arabian Sea $\left(0-15^{\circ} \mathrm{N}, 50-70^{\circ} \mathrm{E}\right)$.

of the Maritime Continent, as well as most of the northern Indian Ocean including the Arabian Sea and Bay of Bengal. It is this region that undergoes the major shifts in wind associated with the Asian summer monsoon. Rather than undergoing a reversal in mid-April as in ERA-40, the low-level winds in HadCM3 change direction about a month earlier in mid-March (Fig. 4). Thus the anticyclone over the Arabian Sea is giving way too early to the Somali jet just north of the equator in the Indian Ocean. The flux adjustments have made no significant alterations to the timing of the monsoon, both in terms of its onset and withdrawal, although at upper levels the winds are about $5 \mathrm{~m} \mathrm{~s}^{-1}$ more westerly in the preceding spring with flux adjustments.

One of the factors contributing to the onset of the Asian summer monsoon is the dramatic warming of the Arabian Sea during spring, as discussed by Ju and Slingo (1995). The observed SSTs rise through March and April and peak in May, before the strong monsoon flow in the form of the Somali jet increases the upper-ocean mixing and evaporation, as well as generating cold upwelling off the Somali coast. Thus SSTs fall, reaching a minimum in August. The retreating monsoon allows temperatures to rise again, peaking again in October. In both versions of the GCM, the same basic temperature cycle is present but substantially damped, as seen in Fig. 5, suggesting that the early monsoon onset in HadCM3 is related to other factors such as land surface warming. After flux adjustments, the peak of Arabian Sea SSTs in May is slightly higher, but since flux adjustments in the Indian Ocean are minimal (Fig. 2), the resulting 
difference between the two model versions is small. This suggests any changes in the nature of the monsoon are communicated by the atmospheric teleconnection to the Pacific, and are not due to different Indian Ocean behaviour. The seasonal cycle in the Arabian Sea is a fundamental error of the model and, as shown by Spencer et al. (2004), is related to major errors in the depth of the mixed layer. It is also possible that the warmth of the Arabian Sea during the monsoon season may be a contributory factor in the overly strong monsoon in HadCM3.

\section{THE ROLE OF THE BASIC STATE IN MONSOON VARIABILITY}

\section{(a) Representation of monsoon variability}

Monsoon variability can be determined in several ways, from the study of the largescale circulation, to more localized indicators such as the rainfall over a particular area of interest. Here, a dynamical monsoon index (DMI), first suggested by Webster and Yang (1992) is used as a measure of the JJAS monsoon strength over the south Asia region $\left(5-20^{\circ} \mathrm{N}, 40-110^{\circ} \mathrm{E}\right)$. The DMI is a measure of the anomalous zonal wind shear, representative of the heating in the atmospheric column of the south Asia region, and defined as

$$
\mathrm{DMI}=\overbrace{\left(U_{850}-\bar{U}_{850}\right)-\left(U_{200}-\bar{U}_{200}\right)} .
$$

The brace indicates area averaging, and all velocities are meaned over the JJAS season. The use of such a measure allows the selection of extreme monsoon summers, which exhibit globally coherent patterns (see e.g. Ju and Slingo 1995; Webster et al. 1998; Sperber et al. 2000). An alternative would be the selection of extreme seasons based on more local rainfall data, such as the AIR time series. However, the extent to which GCMs can represent such localized rainfall variability is limited by their resolution, hence the choice here of the DMI as an index of the strength of the large-scale monsoon circulation. As will be noted later, the results are largely independent of the precise index used.

Those years in which the DMI falls outside half a standard deviation from the mean have been defined as strong or weak monsoons in terms of their circulation. The time series of the DMI for ERA-40 (40 years) and the two GCM integrations (100 years) are shown in Fig. 6, along with the standard deviation for each time series. Note that in HadCM3, the interannual variability of the monsoon circulation is too weak, whereas in HadCM3FA it is too strong.

\section{(b) Monsoon interannual variability in the GCM}

By compositing the dynamically strong and weak monsoon seasons, the global climate anomalies associated with anomalous monsoons can be constructed. Figures 7 and 8 show the strong minus weak difference plots of lower tropospheric wind with precipitation, and surface temperature respectively. These composites could also be made by using the AIR to define strong and weak years. If this is done (not shown here), the overall patterns are very similar to those shown in Figs. 7 and 8, the main difference being that the rainfall signal over India is stronger if AIR is used to define the composites.

Table 1 shows the correlation between the summer monsoon wind strength (DMI) and AIR. For the model integrations the rainfall regions cover the Indian region as described by Gadgil and Sajani (1998). For comparison with the models, the ERA-40 DMI is correlated with the AIR gauge dataset. HadCM3FA features a stronger and more realistic relationship between monsoon dynamics and precipitation, consistent with the results shown in Fig. 7. 


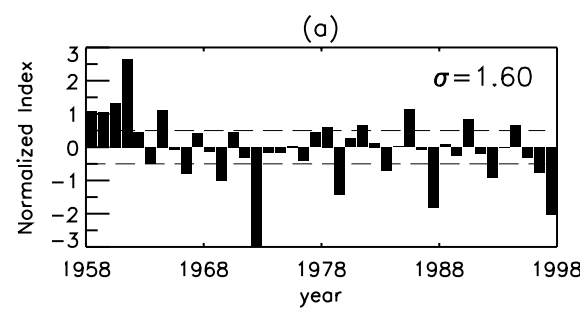

(b)

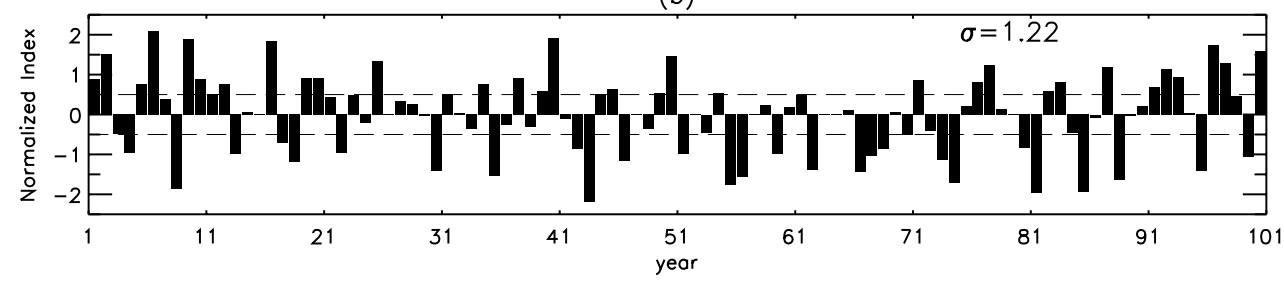

(c)

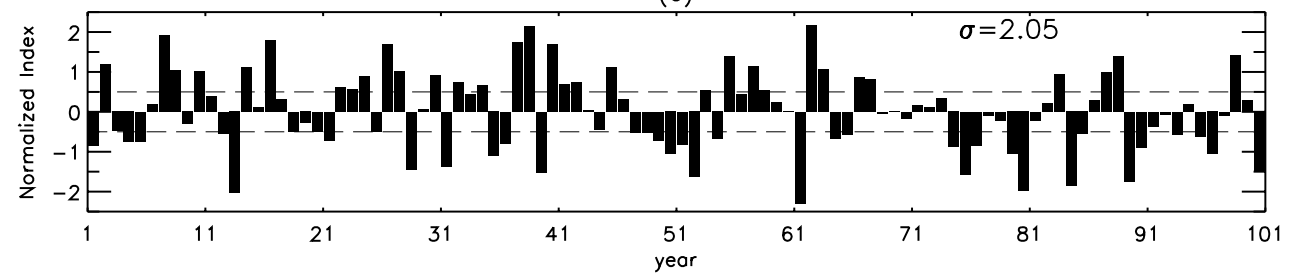

Figure 6. The June-September dynamical monsoon index as defined in Eq. (1), averaged over 5-20 $\mathrm{N}, 40$ $110^{\circ} \mathrm{E}$ for (a) ERA-40, (b) HadCM3 and (c) HadCM3FA, as first used by Webster and Yang (1992). Note that the years in the two model runs are entirely independent.

In the reanalysis, strong monsoons have several characteristics, both local to India and further afield. Figure 7(a) shows stronger easterly trade winds across all of the equatorial Pacific during strong monsoon summers. This is a well-known signature of strong monsoons, as suggested by Webster and Yang (1992) and Webster et al. (1998). The south Pacific high is also found to be stronger, as noted by Meehl (1987). Figure 7(a) clearly shows a stronger south-westerly monsoon flow across India, continuing on over Thailand and Burma. As expected, India is wetter in strong monsoon years, but there are also precipitation signals elsewhere, with the north-west Maritime Continent and equatorial Pacific being drier and the south-east Maritime Continent wetter.

In terms of surface temperatures (Fig. 8(a)), the results from ERA-40 show that SSTs in the central to eastern Pacific are reduced by up to $2 \mathrm{~K}$ during strong monsoons, characteristic of a La Niña pattern and consistent with cold upwelling in the east and Ekman divergence at the surface with the strengthened trades. The stronger monsoon flow over the Arabian Sea causes stronger upwelling and increased evaporation, resulting in local cooling. Indian land surface temperatures are up to $2 \mathrm{~K}$ cooler during strong monsoon summers, consistent with increased precipitation over the subcontinent (Fig. 7(a)).

HadCM3 represents correctly some of the features associated with monsoon interannual variability, but other aspects are less well captured. The monsoon flow across the Arabian Sea and India is stronger during strong monsoons, but this strengthening does not extend across the Bay of Bengal. Instead there is an increase in westerly flow on the equator in the eastern Indian Ocean, which is the equatorial branch of a cyclonic 
(a)

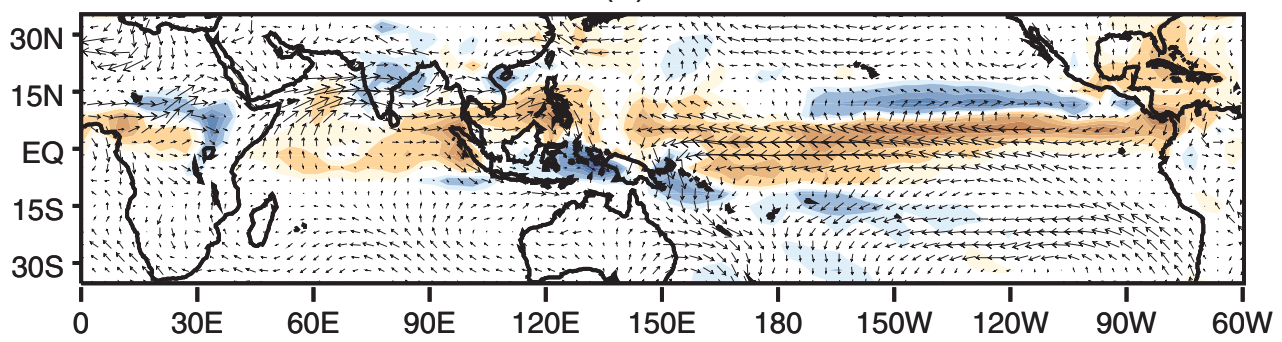

(b)

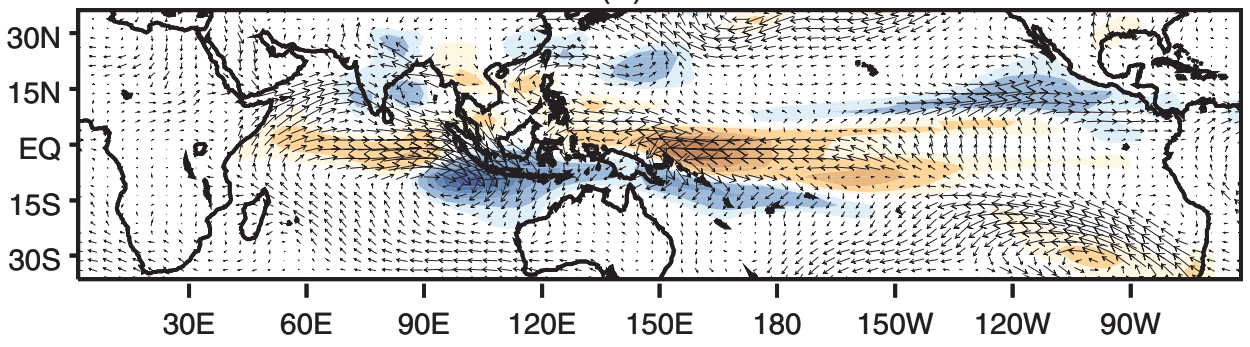

(c)

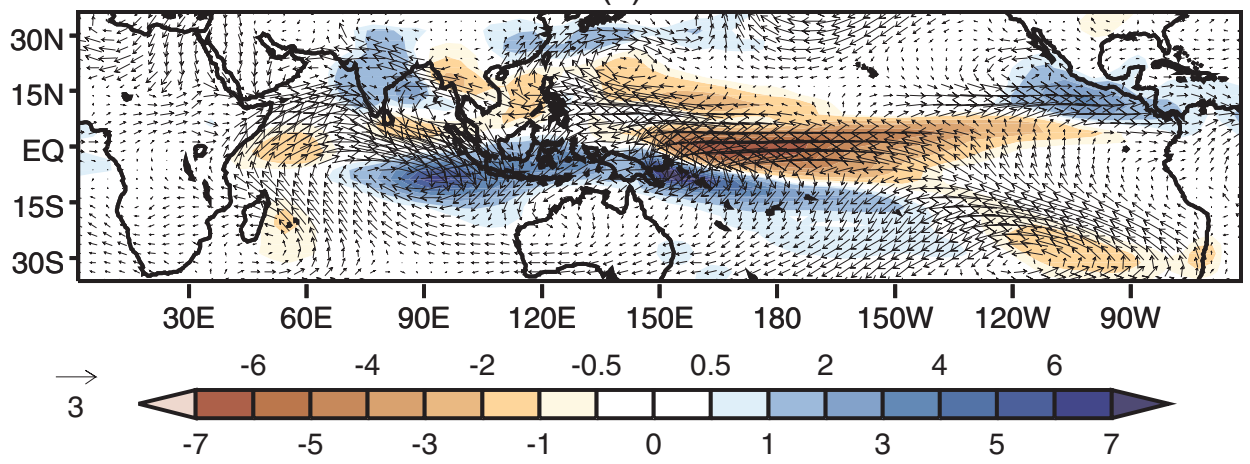

Figure 7. Strong minus weak year composite difference plots of lower tropospheric (850 mb) winds (vectors) and precipitation (mm day ${ }^{-1}$, colour shading) for (a) ERA-40, (b) HadCM3, and (c) HadCM3FA. The unit wind vector is $3 \mathrm{~m} \mathrm{~s}^{-1}$.

circulation in the southern Indian Ocean. The circulation error present over the Bay of Bengal in both versions of the GCM indicates a tendency of the models to have very tight zonal structures, an independent error not alleviated by flux adjustments.

The increase in precipitation over India during strong monsoons in HadCM3 is rather weak. The strengthening of the Pacific trade winds is confined to the western Pacific, and the associated reduction in precipitation is also largely confined to the west of the Date Line. The SST anomaly pattern associated with strong versus weak monsoons in HadCM3 (Fig. 8(b)) shows only a weak association with ENSO, although the cooling of the Indian Ocean and subcontinent surface are reasonably well captured. The largest negative SST anomalies occur near the Date Line rather than in the east Pacific, which, with the strengthened trades only over the west Pacific, may be associated with the warm pool confinement in HadCM3. 
(a)

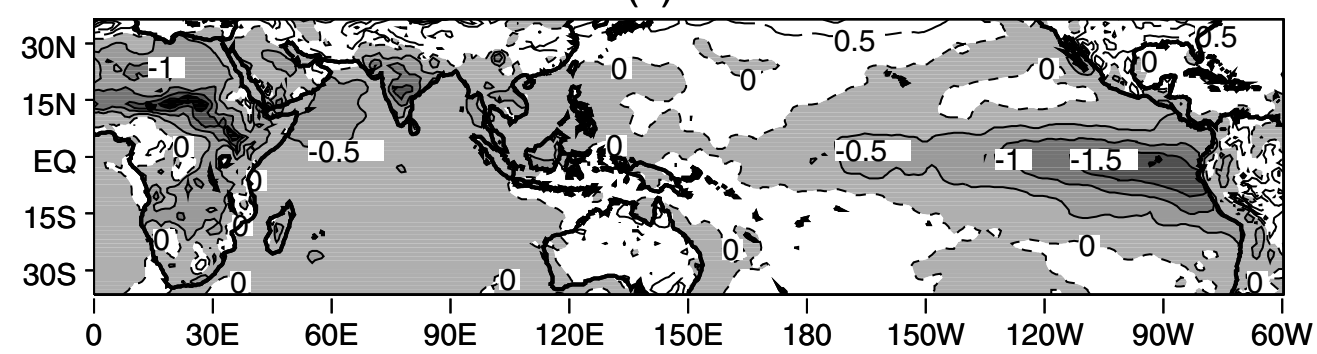

(b)

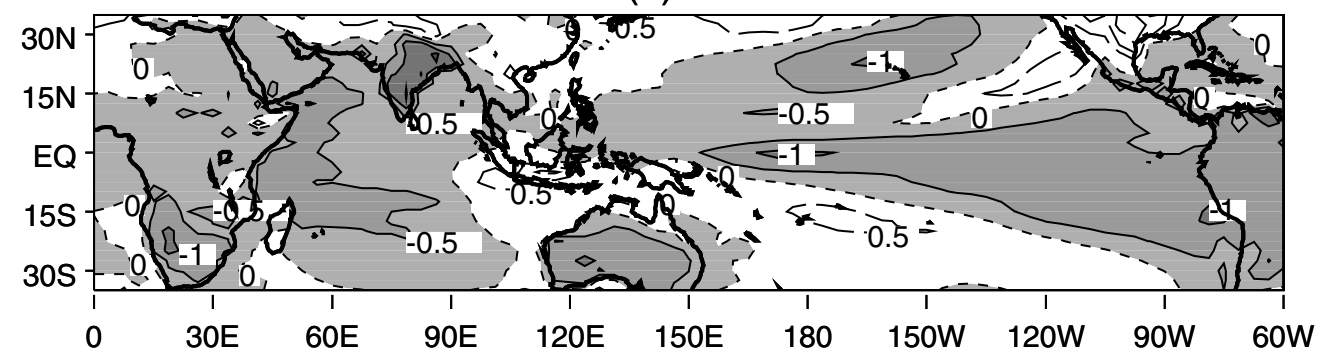

(c)

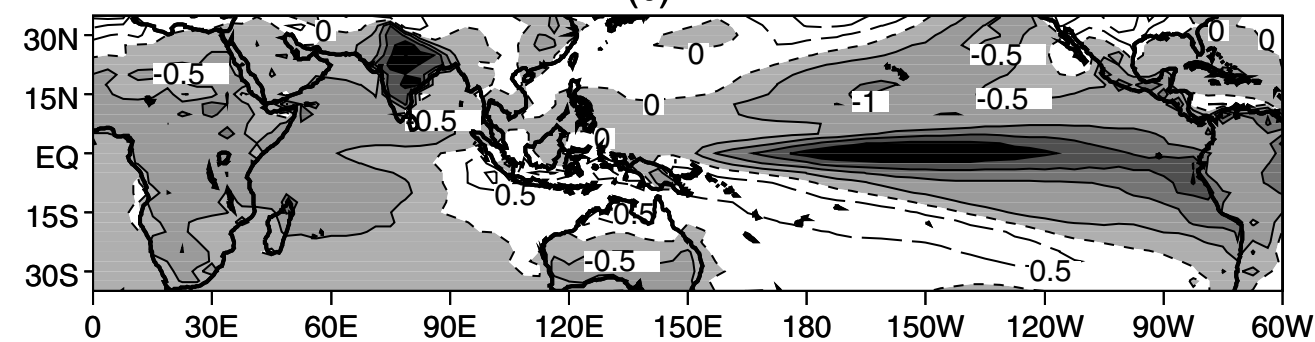

Figure 8. As Fig. 7, but for surface temperature (contour interval $0.5 \mathrm{~K}$ ). Negative differences are shaded and dashed contours show positive differences.

TABLE 1. CorRelation BeTWEen THE JUNE-

SEPTEMBER ALL-INDiA RAINFALL AND THE DYNAMICAL MONSOON INDEX FOR THE TWO HADCM MODELS AND THE REANALYSIS

\begin{tabular}{ccc}
\hline HadCM3 & HadCM3FA & ERA-40 \\
\hline 0.25 & 0.47 & 0.55 \\
\hline
\end{tabular}

The flux adjustments in HadCM3FA have a significant effect on the interannual variability both of the monsoon and in the Pacific sector (Figs. 7(c) and 8(c)). Consistent with the increase in the standard deviation of the DMI in HadCM3FA, the strong minus weak monsoon differences are also larger than in HadCM3. However, there are also changes to the patterns of wind, precipitation and SST differences. The enhancement of the Pacific trades during strong monsoon years now extends further to the east, with the associated reduced precipitation anomaly also extending further across the Pacific, 


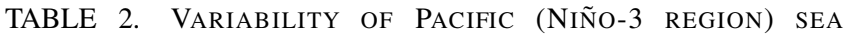
SURFACE TEMPERATURE $(\mathrm{K})$

\begin{tabular}{lrcr}
\hline & HadCM3 & HadCM3FA & ERA-40 \\
\hline Mean & 299.30 & 299.35 & 299.18 \\
Standard deviations & & & \\
$\quad$ annual cycle & 0.76 & 0.82 & 0.89 \\
$\quad$ seasonally adjusted & 0.94 & 1.21 & 0.85 \\
\hline
\end{tabular}

The Niño-3 region is $5^{\circ} \mathrm{N}-5^{\circ} \mathrm{S}, 150-90^{\circ} \mathrm{W}$.

(a)

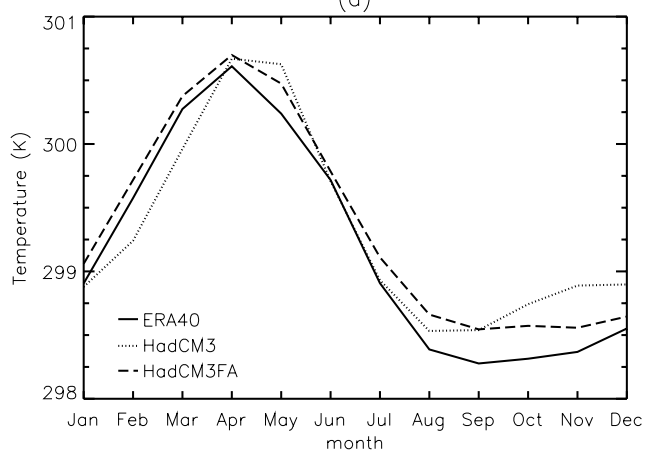

(b)

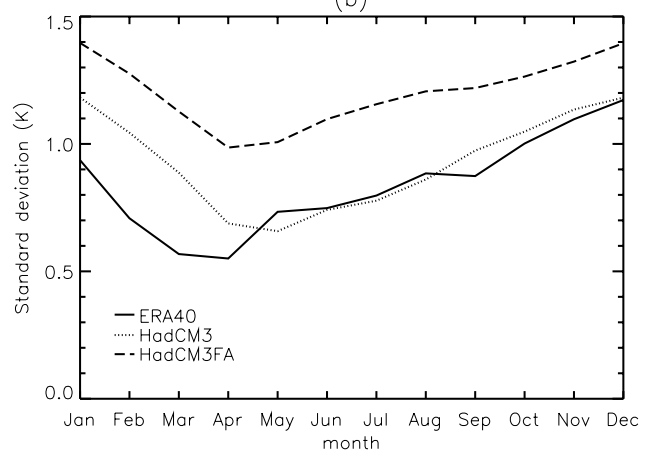

Figure 9. The Niño-3 region annual cycle of sea surface temperature for ERA-40, HadCM3, and HadCM3FA: (a) mean and (b) interannual standard deviation.

although the maximum precipitation anomaly is still near the Date Line. The La Niñalike SST signal is much stronger in HadCM3FA than HadCM3, although it still extends too far to the west, and remains very equatorially confined. This stronger signal in equatorial SST indicates a potentially stronger teleconnection between ENSO and the monsoon in HadCM3FA, which will be investigated in subsequent sections. Over the Indian sector, the pattern of the strong minus weak signal in HadCM3FA is generally the same as HadCM3 but rather stronger, particularly the enhanced westerly flow near the equator. The rainfall signal over India itself is also stronger than in HadCM3, despite the weakened summer-mean Indian rainfall shown in Fig. 3. This suggests that stronger monsoon perturbations in HadCM3FA are due to stronger ENSO.

\section{THE IMPACT OF THE BASIC STATE ON ENSO VARIABILITY}

As Fig. 8 shows, the equatorial Pacific SST signal associated with interannual variability of the DMI is far stronger in the GCM when flux adjustments are applied, indicating that the teleconnection between ENSO and the monsoon is potentially much stronger in this version of the model. Before this teleconnection is investigated in more detail, the nature of ENSO itself in each of the model experiments needs to be evaluated. Standard deviations of the seasonally adjusted SST time series (i.e. with the climatological cycle removed) for the Niño-3 region are shown in Table 2 as a simple indicator of interannual variability. HadCM3FA has a larger standard deviation than HadCM3, which itself is slightly larger than the observed value.

The mean annual cycle of Niño-3 region SSTs provides a useful indication of the performance of a GCM in simulating equatorial Pacific SST. Figure 9(a) shows that the mean seasonal cycle of Niño-3 SSTs is well captured by both versions of the model. However, the use of flux adjustments to correct the mean state in the Indo-Pacific warm 


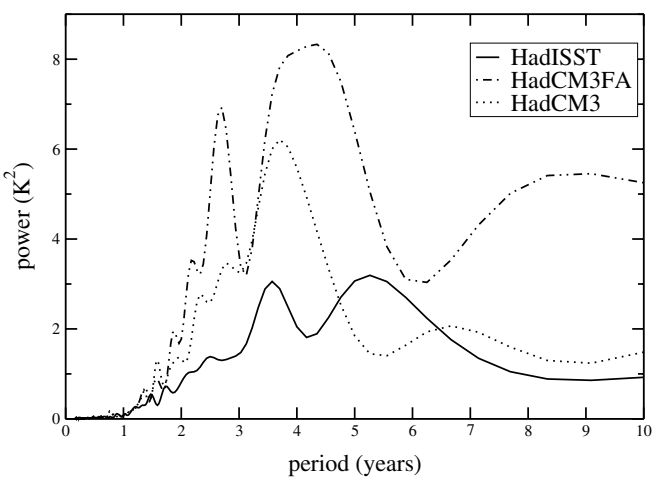

Figure 10. Power spectra of seasonally adjusted Niño-3 region SSTs in the 100-year HadISST dataset and the HadCM3 and HadCM3FA model integrations.

pool has had a significant impact on the interannual variability of the Niño-3 SSTs. Figure 9(b) shows the interannual standard deviation of Niño-3 SST anomalies for each month of the year. The standard deviation in all months is higher in HadCM3FA than HadCM3, further substantiating the enhanced SST variability in the adjusted model. The ERA-40 data indicate phase-locking of east Pacific SST variability to the annual cycle, with weakest variability in April and strongest in December, as found by, amongst others, Latif et al. (2001). In contrast, HadCM3 has its minimum variability slightly too late, in May, which is partially corrected in HadCM3FA. However, it is worth noting that both model versions perform well in their representation of the annual cycle of Niño-3 SSTs when compared with other coupled models studied by Latif et al. (2001).

Another impact of flux adjustment has been its effect on the periodicity and regularity of El Niño. Figure 10 shows the power spectra of seasonally adjusted Niño-3 region SST anomalies. In this figure the extended Hadley Centre observed SST dataset (HadISST, Rayner et al. 2003) for the period 1900 to 1999 is used to give a comparable length of record to the model integrations. As noted by Guilyardi et al. (2004), the HadCM3 spectrum is strongly peaked at timescales between 3 and 4 years, indicating that ENSO in HadCM3 is too periodic. In HadCM3FA, variability at all time periods is stronger, and there is a broader distribution of power across a range of frequencies. One explanation for the increased SST variability may lie in the warmer mean climate resulting from the flux adjustments. Codron et al. (2001), using a different coupled GCM, found that a warmer mean state in the Pacific caused interannual SST variability in the region to double. The current work confirms their results that the variability of tropical oceans is very sensitive to the mean state. The improved mean state has made the thermocline more intense (see section 3), and Meehl et al. (2001) have argued that those models with a high ENSO amplitude share this characteristic. Interestingly, the power spectrum for HadCM3FA shows much increased power on biennial timescales, and this will be discussed in section 6 .

The trade wind response to Niño-3 SST variations gives a simple indication of the coupling strength in a GCM. Figure 11 shows the relationship between the $10 \mathrm{~m}$ zonal winds in the Niño-4 region $\left(5^{\circ} \mathrm{N}-5^{\circ} \mathrm{S}, 160^{\circ} \mathrm{E}-150^{\circ} \mathrm{W}\right)$ and the Niño-3 SST anomalies, computed from monthly mean data for each of the three datasets. The regression coefficients (gradient of the best-fit lines) are also shown. The distribution of Niño-3 SSTs in ERA-40 in Fig. 5 shows more frequent but minor cool events (La Niña), together with fewer but stronger east Pacific warmings (El Niño), whereas the two versions of 
(a)

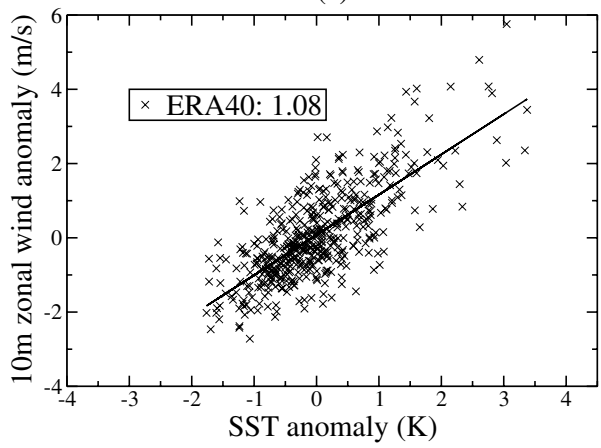

(b)

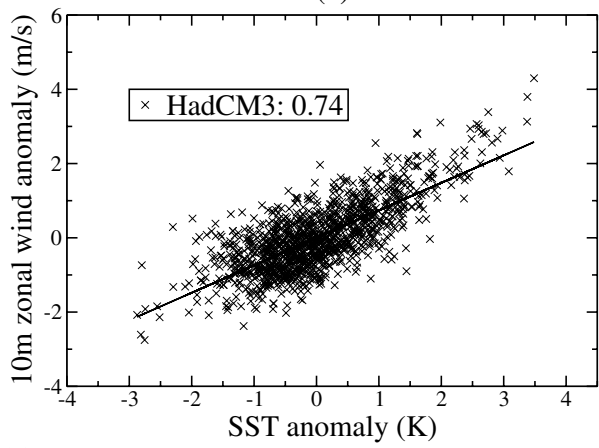

(c)

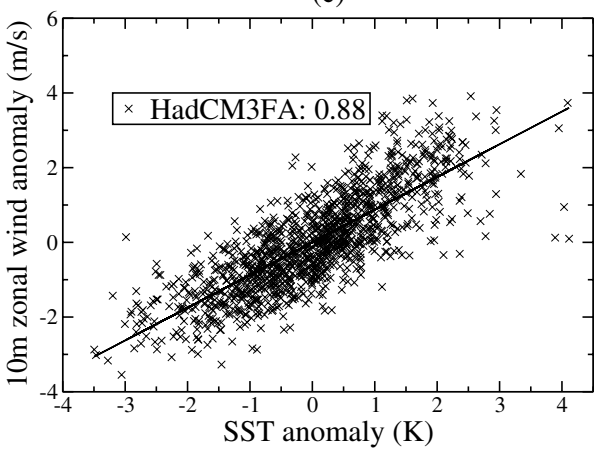

Figure 11. Monthly Niño-4 region $10 \mathrm{~m}$ zonal wind anomalies plotted against Niño-3 region SST anomalies for (a) ERA-40, (b) HadCM3 and (c) HadCM3FA. The coefficients shown are gradients $\left(\mathrm{m} \mathrm{s}^{-1} \mathrm{~K}^{-1}\right)$ of the best-fit lines.

the model tend towards a normal distribution, only slightly biased to a greater number of cold events. When considering the ocean-atmosphere coupling, it is clear that the variability of central Pacific trade winds in HadCM3FA is more closely coupled to Niño-3 SST variability than in HadCM3, although neither model version reproduces the observed strength of this relationship. This suggests that the surface winds in HadCM3FA can respond more realistically to east Pacific SST variations once some of the systematic biases have been removed. The more intense thermocline found in the flux-adjusted model allows equatorial upwelling to tap into sub-thermocline waters more readily when a given wind variation is applied.

Lengaigne et al. (2004) describe how a single strong equatorial west Pacific westerly wind event (WWE), applied to a coupled ocean-atmosphere model, was able to excite an El Niño in part through the generation of a downwelling Kelvin wave that propagates eastwards, causing SST anomalies in the east Pacific. In addition, the WWE caused an eastward extension of the warm pool, thus allowing convection and subsequent WWEs to extend further into the Pacific, reinforcing the developing El Niño. Their results suggest that stochastic forcing can broaden the spectrum of Niño-3 SST variability, moving the ENSO cycle away from a slowly evolving, rather predictable oscillation. Although a detailed study of the ENSO dynamics in HadCM3 is beyond the scope of this study, the occurrence of WWEs in the two model versions has been analysed. Figure 12 shows the number of WWEs of varying strengths that persist for longer than 5 days in ERA-40 and in the HadCM3 and HadCM3FA models. Flux adjustment removes some of the easterly bias inherent in HadCM3, so thresholds have 
(a)

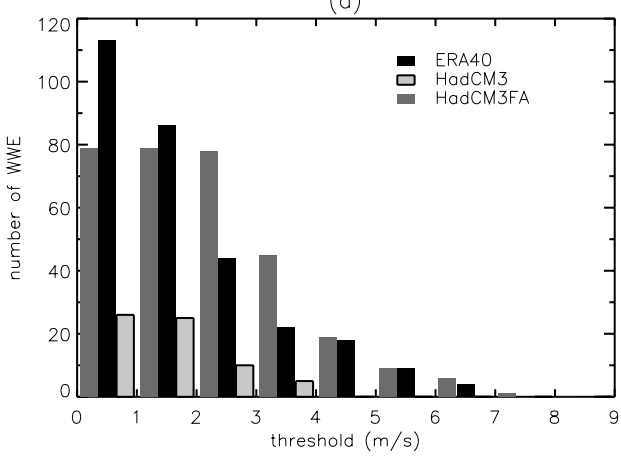

(b)

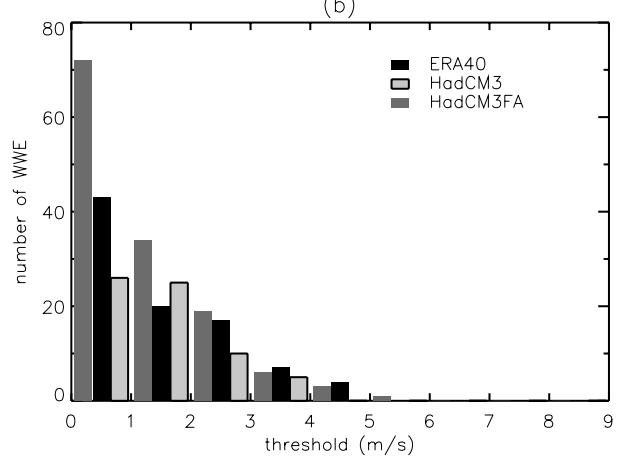

Figure 12. Number of westerly wind events exceeding the given threshold which persist for longer than 5 days in 40 years of daily data from ERA-40, HadCM3, and HadCM3FA, with (a) unadjusted and (b) adjusted thresholds (see text). The count was made in the $1.25^{\circ} \mathrm{N}-1.25^{\circ} \mathrm{S}, 148.175-178.175^{\circ} \mathrm{E}$ region.

been adjusted in Fig. 12(b) to take account of the mean zonal wind strength in the west Pacific in the different GCM versions. The figures show more and stronger WWEs in the flux-adjusted model, consistent with improved simulation of the MJO, as found by Inness et al. (2003). The greater stochastic forcing on intraseasonal timescales in HadCM3FA may contribute to the less regular ENSO cycle, already noted in Fig. 10.

The different nature of ENSO in HadCM3FA will obviously have a global impact through remote teleconnections. The influence of ENSO on global SST can be seen by correlating Niño-3 temperatures with global surface temperatures, as in Fig. 13. In ERA-40 strong positive correlations extend broadly over the east Pacific, with a horseshoe pattern of negative correlations around this region. The positive correlations over the Indian Ocean indicate the result of atmospheric teleconnections with El Niño (see e.g. Spencer et al. 2005). HadCM3 captures the main features of this pattern but with some differences. The positive correlations in the equatorial Pacific extend too far west, splitting the horseshoe pattern of negative correlations into two branches. In the east Pacific, the pattern is rather meridionally confined, a feature common to many coupled models. With flux adjustment, there is some improvement in the pattern of correlations over the Pacific although the Indian Ocean teleconnection has become consistently stronger, indicating that ENSO now has a greater bearing on behaviour in the Indian sector, as evident also in Fig. 8. The strong link between the Pacific and Indian sectors in HadCM3FA is consistent with a TBO system described by Meehl and Arblaster (2002a,b) and Meehl et al. (2003).

El Niño evolution can be described by lag-lead correlations of Niño-3 SSTs with SSTs across the whole of the equatorial Pacific. Figure 14 shows the correlations between winter season (December-February, DJF) Niño-3 SSTs and monthly meaned equatorial $\left(2.5^{\circ} \mathrm{N}-2.5^{\circ} \mathrm{S}\right)$ Pacific SSTs for the 18 months preceding and following the peak of El Niño. The correlations with the ERA-40 data indicate that El Niño is associated with warming across the central and east Pacific, as well as cooling of the west Pacific warm pool as the thermocline deepens in the east and rises in the west. In the winter and spring before the peak of El Niño, a lobe of positive correlations is seen in the region $150-180^{\circ} \mathrm{E}$, representing pre-El Niño extension of the warm pool, often associated with anomalous westerlies (see e.g. Lengaigne et al. 2002). As already noted in Fig. 13, El Niño extends too far west in HadCM3, and the confinement of the warm pool means that the negative correlations at $140^{\circ} \mathrm{E}$ are limited when compared 
(a)

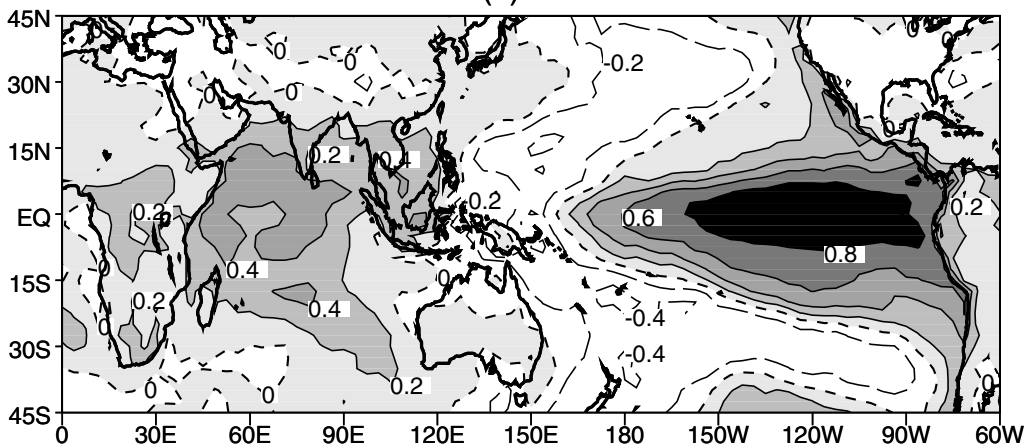

(b)

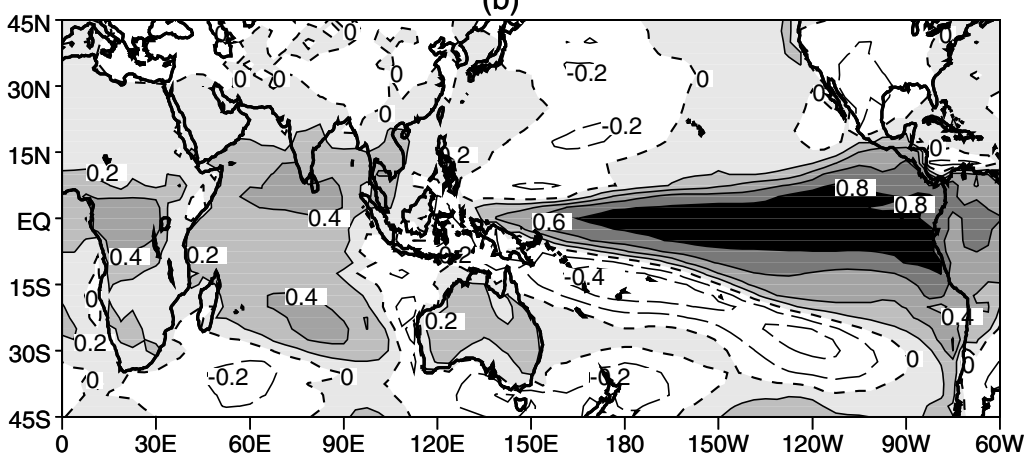

(c)

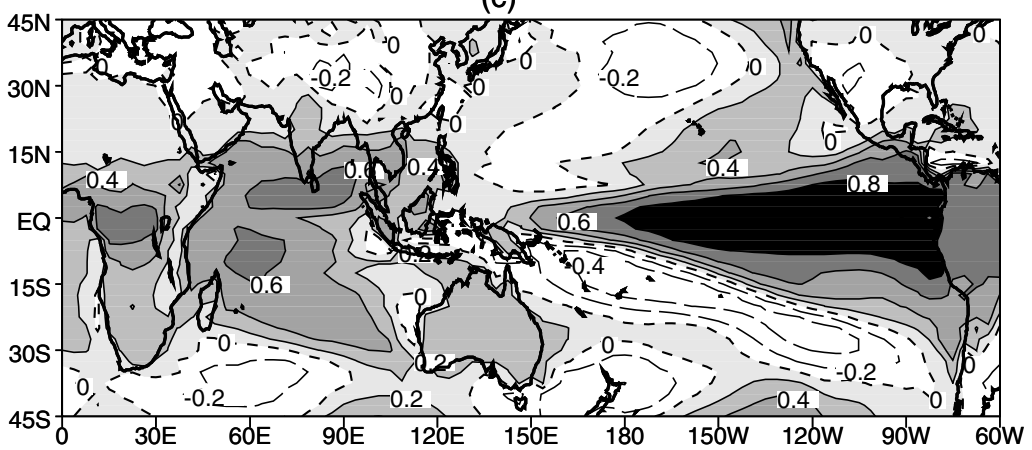

Figure 13. Concurrent correlations (contour interval 0.2) between Niño-3 region and global sea surface temperatures in (a) ERA-40, (b) HadCM3, and (c) HadCM3FA. Positive correlation regions are shaded and dashed lines show negative correlations. Correlations are significant in all but $5 \%$ of cases outside \pm 0.2 for the 100 -year model runs and \pm 0.31 for ERA-40.

to observations. In addition, there is no proper representation of the pre-El Niño warm pool extension, potentially an important part of the evolution of ENSO. The negative correlations before and after El Niño are also too strong, in part because El Niño in HadCM3 is too regular, with a periodicity in the region of 36 months. This regularity was also noted in the Centre Nationale de Recherche Météorologiques coupled model by Ashrit et al. (2003).

Flux adjustments lead to some improvements in the evolution of El Niño. There is now some evidence, albeit weak, of negative correlations in the west Pacific. The presence of a positive lobe in spring between 150 and $180^{\circ} \mathrm{E}$ in Fig. 14(c) shows 
(a)

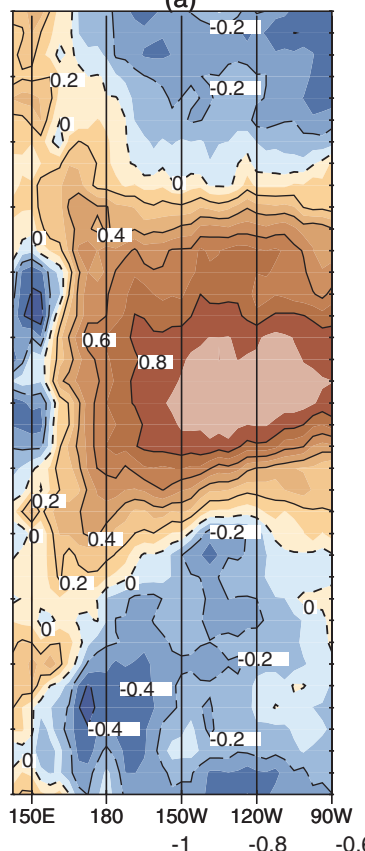

(b)

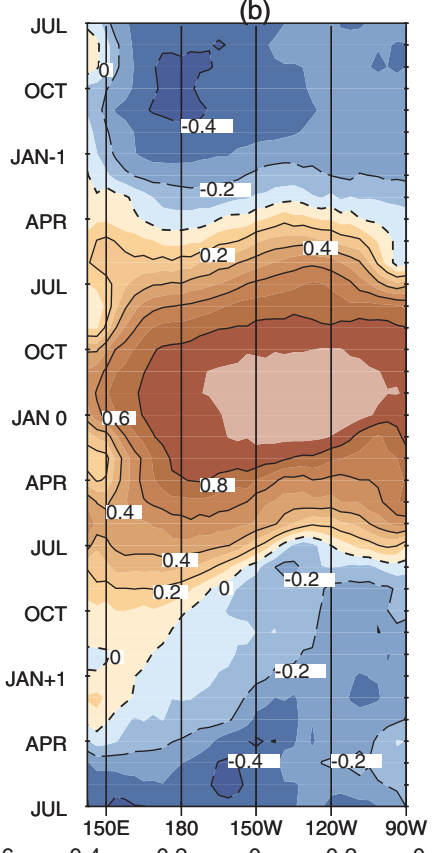

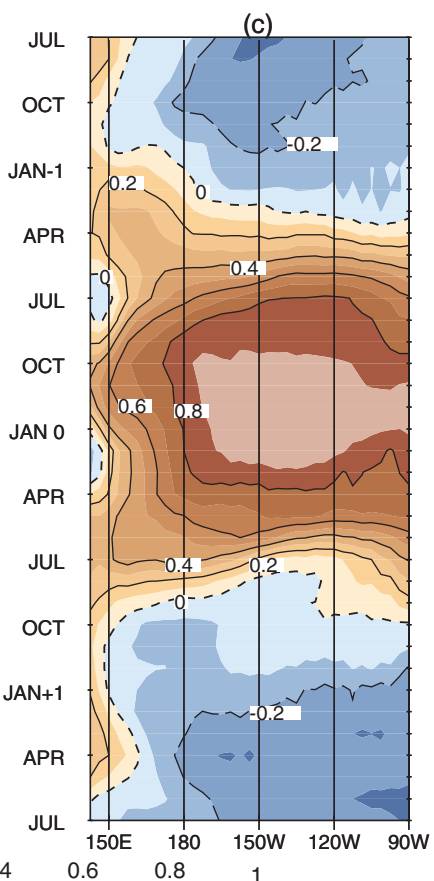

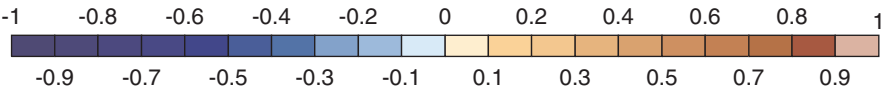

Figure 14. Lag correlations between winter season (December-February) Niño-3 region sea surface temperatures (SSTs) and monthly equatorial Pacific $\left(2.5^{\circ} \mathrm{N}-2.5^{\circ} \mathrm{S}\right)$ SSTs in (a) ERA-40, (b) HadCM3, and (c) HadCM3FA. Negative correlation contours are dashed. Significance levels are as in Fig. 13.
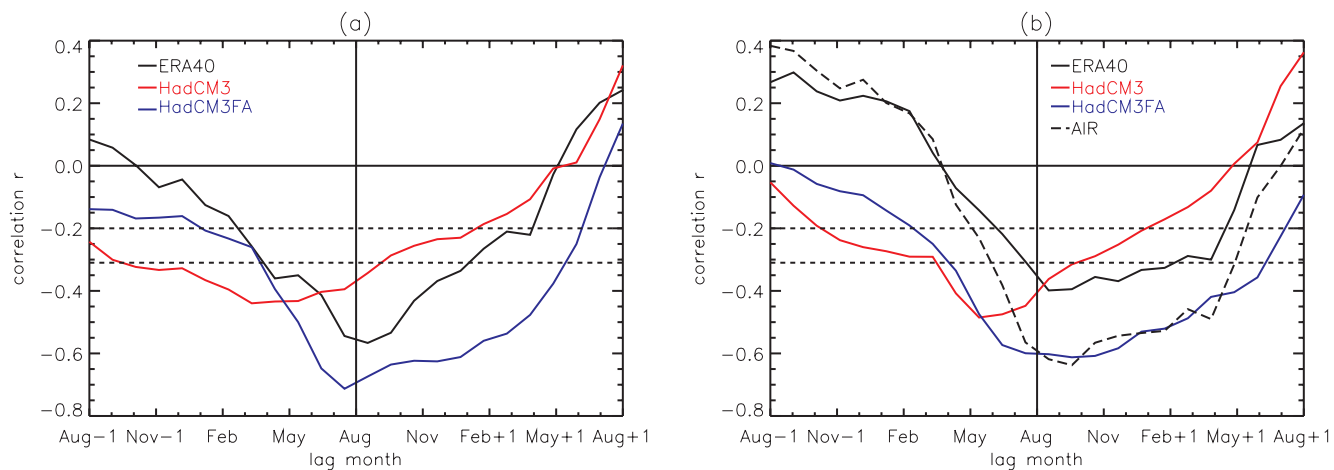

Figure 15. Correlation plotted against lag time between Niño-3 region sea surface temperature (SST) and summer (June-September) (a) dynamical monsoon index and (b) All-Indian Rainfall. In (b), 'AIR' denotes AllIndia Rainfall data being correlated with ERA-40 SSTs. 'Aug-1' indicates the August Niño-3 anomaly the year before the measured rainfall. Correlations significant in all but $5 \%$ of cases are indicated outside the dashed lines: $|r|>0.31$ for the 40 -year datasets, $|r|>0.20$ for the 100-year datasets.

that HadCM3FA is reproducing the pre-El Niño warm pool extension, consistent with the increased westerly wind activity shown in Fig. 12. The negative correlations in the boreal summers are less pronounced in HadCM3FA, indicating again that ENSO is less periodic in its strongest mode, supporting Fig. 10. 


\section{THE BASIC STATE AND MONSOON-ENSO TELECONNECTIONS}

The monsoon-ENSO teleconnection is arguably the strongest link between the Asian summer monsoon and other global phenomena, and has been studied as far back as the 1920s by Gilbert Walker (e.g. Webster and Yang 1992). In coupled models used for seasonal prediction of the monsoon, it is therefore important that the Pacific SSTs are well simulated, and also that the signal from the equatorial Pacific is correctly transmitted to the monsoon region.

It was shown in section 4 that there is a stronger Pacific SST signal during anomalous monsoon years when flux adjustments are applied to HadCM3, suggesting a stronger teleconnection, and in section 5 that the interannual Niño-3 variability is stronger and less regular in HadCM3FA than the standard version of the GCM. The monsoon-ENSO teleconnection will now be examined in more detail. Figure 15 shows the correlation between the monthly Niño-3 time series (through the whole year) and indices of the strength of the summer monsoon. Considering first the large-scale monsoon variability, represented by the DMI, Figure 15(a) shows that in ERA-40, the strongest inverse correlation occurs in the middle of the monsoon season, between July and August. Thus high boreal summer surface temperatures in the Niño-3 region (El Niño) correlate well with dynamically weak monsoons in agreement with many other studies (e.g. Shukla and Paolino 1983; Webster and Yang 1992). Prior to the monsoon the negative correlations only become significant during March-April, a manifestation of the predictability barrier first suggested by Webster and Yang (1992), in which equatorial Pacific SST conditions prior to April are of little use in summer monsoon prediction. Furthermore, the ERA-40 results show slightly larger negative correlations after the monsoon than before, suggesting that the monsoon leads El Niño.

HadCM3 does not represent the timing of the teleconnection correctly, instead finding May Niño-3 SSTs to be most strongly correlated with monsoon strength (Fig. 15(a)). The shape of the correlation curve is also incorrect, with no obvious spring predictability barrier; instead the negative correlations are significant from the preceding autumn. Also the lag correlations after the monsoon are insignificant, suggesting that in HadCM3 the monsoon has little influence on El Niño. Thus HadCM3 is not correctly reproducing the monsoon-ENSO teleconnection, even though the mean monsoon is quite well simulated. By correcting the systematic errors in the Indo-Pacific region, the teleconnections between the monsoon and ENSO are dramatically improved in HadCM3FA. The maximum negative correlation now occurs in summer although its strength supports the result that ENSO plays a more dominant role in monsoon behaviour than before. The spring predictability barrier is also simulated in HadCM3FA, with the negative correlation being insignificant until March preceding the monsoon. The asymmetry in the lead-lag correlations is even more pronounced in HadCM3FA than in ERA-40, suggesting that the monsoon has a significant influence on the evolution of El Niño. Hence in HadCM3FA the monsoon could be regarded as becoming, 'more active in world weather', to paraphrase Normand (1953).

Looking back at the Pacific SST power spectra in Fig. 10, increased power is found at quasi-biennial timescales in HadCM3FA. Kim and Lau (2001) found the key to quasibiennial tendency in El Niño evolution to lie in the strong coupling of ENSO to monsoon wind forcing in the west Pacific. Manually increasing the surface wind response to SST anomalies in their simplified GCM made the ENSO system more biennial, and in our study Fig. 11 indicates that the air-sea coupling strength has increased in HadCM3FA. Lau and $\mathrm{Wu}$ (2001) noted some observational evidence for strong monsoon-ENSO interactions during El Niño events with a strong biennial tendency, whilst $\mathrm{Wu}$ and Kirtman (2004) found that a strong biennial tendency was possibly due to the strong 


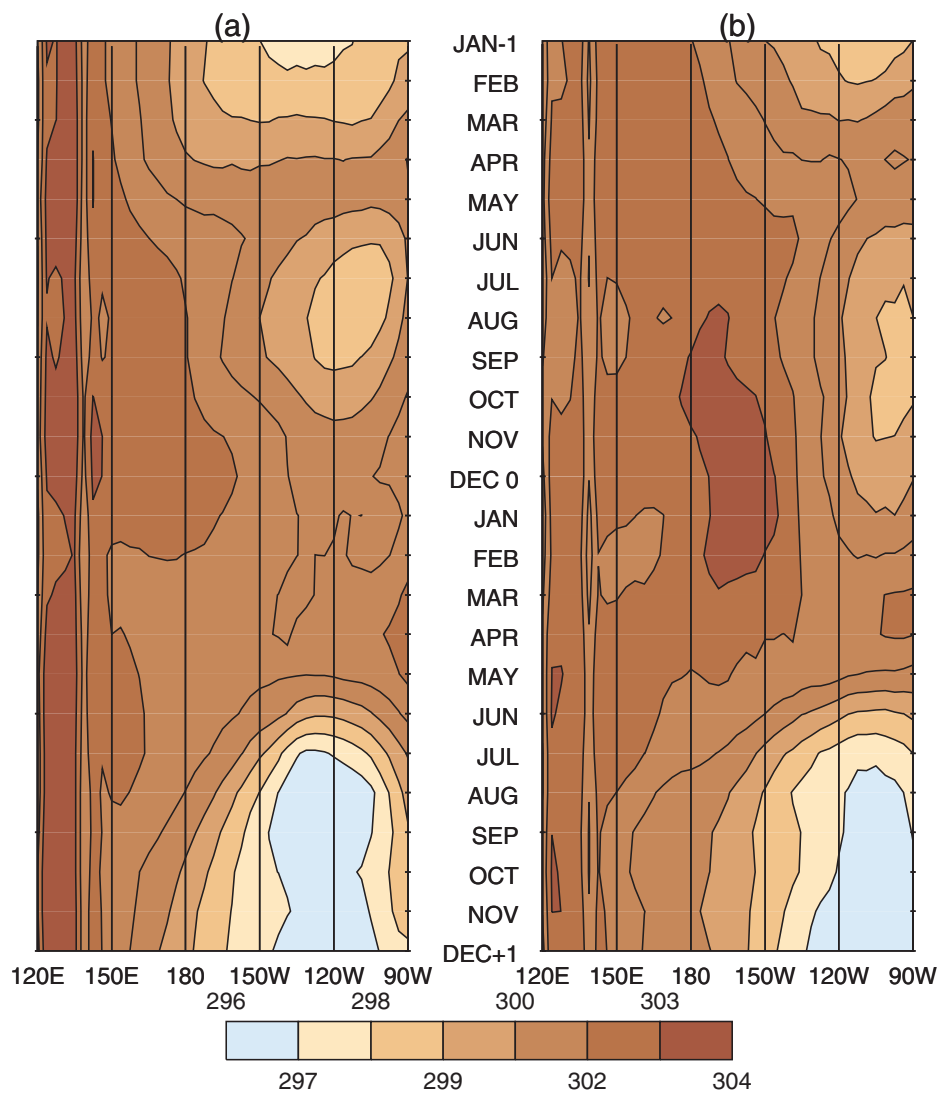

Figure 16. Evolution of mean equatorial $\left(2.5^{\circ} \mathrm{S}-2.5^{\circ} \mathrm{N}\right)$ sea surface temperatures $(\mathrm{K})$ in a composite of ten El Niño events in (a) HadCM3 and (b) HadCM3FA.

monsoon-ENSO interaction in their model. However, they concede that systematic model bias may also be the cause, illustrating the difficulty in drawing such conclusions in coupled model experiments.

So far the monsoon-ENSO teleconnection has been described in terms of the DMI. It might be argued that a more localized index such as AIR is more relevant to the seasonal forecasting issue. Figure 15(b) also shows lag-lead correlations with east Pacific (Niño-3) SSTs, but this time with seasonal (JJAS) AIR from Parthasarathy et al. (1994). The grid squares chosen for the Indian region in the models were as in Gadgil and Sajani (1998). ERA-40 rainfall data were interpolated onto the model grid, allowing the same squares to be selected. The results show that only with flux adjustment is the model able to capture the seasonality of the teleconnections between the monsoon and ENSO. Again the asymmetry in the lead-lag correlations support the role of the monsoon as an active rather than passive player in El Niño, and that it is only HadCM3FA that is able to capture that role. Interestingly, comparison of the results from ERA-40 with those from the observed AIR suggests that the reanalysis is barely able to capture the known correlation between monsoon rainfall and ENSO.

The greater amplitude of ENSO has some role to play in the strengthening of its teleconnection with the monsoon. However, this only forms part of the argument. Looking again at El Niño evolution, ten warm events have been composited from each model integration into a two-year period, shown in Fig. 16. This equatorial composite 
shows SSTs rising to the peak in boreal winter then falling afterwards. The warmest waters are clearly shifted eastward in HadCM3FA, extending past the Date Line. So the reduction in the mean state zonal temperature gradient and warmer central Pacific project onto the ENSO system. The strong teleconnection in HadCM3FA must be due to a combination of both the larger ENSO amplitude and an improved (warmer) mean state. The warmer mean state means that weak El Niño events in HadCM3FA will be more likely to drive the monsoon system via the teleconnection than in HadCM3, whilst larger events caused by the higher amplitude will push the highest absolute SSTs even further east into the teleconnection region, further strengthening the connection with the monsoon.

\section{CONCLUSIONS}

The substantial change in the strength and timing of the monsoon-ENSO teleconnection when flux adjustment is used in the equatorial Indo-Pacific region is a striking result that has important implications for the seasonal predictability of the monsoon. As described in the previous sections, using flux adjustments to improve the basic state of a coupled model has had several impacts. Both HadCM3 and HadCM3FA simulate the mean characteristics of the Asian summer monsoon reasonably well. However, HadCM3 has significant errors in equatorial Pacific SST, low-level winds and precipitation, which are largely corrected when a minimal set of flux adjustments are applied in the equatorial Indian and Pacific Oceans. As a result, the interannual variability of the Asian monsoon increases from being too weak in HadCM3 to being somewhat stronger than observed in HadCM3FA, whilst the teleconnection between east Pacific SSTs and the monsoon is significantly improved. The improved basic state means that the warmest SSTs along the equator are moved further east during El Niño events. This warm water takes the convection with it, shifting the rising branch of the Pacific Walker circulation, and strengthening the teleconnection in the Niño-3 region. ENSO variability becomes stronger in HadCM3FA, feeding back to further strengthen the teleconnection, and the spectrum of Niño-3 variability is also broadened, possibly due to an increase in stochastic forcing in this version of the model. ENSO behaviour on biennial timescales is also increased, related to the strengthened monsoon-ENSO coupling. Thus changes in the basic state climate of a coupled model can have significant impacts on the behaviour of El Niño and on the simulation of teleconnection patterns that are known to lend predictability to regionally important circulation patterns such as the Asian monsoon.

The changes in monsoon-ENSO teleconnection strength and timing when the basic state of the GCM is changed have important implications for the use of coupled GCMs in seasonal prediction. Most coupled GCMs develop significant systematic errors over the period of a seasonal forecast integration, and so a common technique is to linearly subtract the mean state of the model from the forecast fields to produce 'anomaly forecasts'. However, if the model biases are themselves leading to incorrect representations of the SST variability and their teleconnections that partially drive seasonal to interannual variations in weather patterns, this anomaly forecast approach would not be sufficient to compensate for the biases in the GCM. In other words, as the results of this study have demonstrated, the coupled system is far from linear. A pragmatic solution to this problem may be the adoption of flux adjustment techniques in seasonal forecast models to constrain the basic state of the model whilst still allowing internal variability of the coupled climate system. Whilst such an approach is considered unacceptable for long-term climate change prediction, it may still have potentially beneficial applications in seasonal forecasting. 


\section{ACKNOWLEDGEMENTS}

A. G. Turner is supported through a PhD studentship provided by the NERC Centres for Atmospheric Science (NCAS). P. M. Inness and J. M. Slingo are funded by the NCAS Centre for Global Atmospheric Modelling. The authors wish to thank the British Atmospheric Data Centre for supplying the ERA-40 dataset, the Climate Prediction Center for making available their CMAP dataset, and the Indian Institute of Tropical Meteorology, Pune, for the AIR dataset. Computing resources for running the Unified Model were provided by Computer Services for Academic Research. The authors are also grateful to the Associate Editor, H. Hendon, and two anonymous reviewers for their useful comments.

Ashrit, R., Douville, H. and Kumar, K.

Charney, J. G. and Shukla, J.

Codron, F., Vintileos, A. and Sadourny, R.

Gadgil, S. and Sajani, S.

Gordon, C., Cooper, C., Senior, C. A., Banks, H., Gregory, J. M., Johns, T. C., Mitchell, J. F. B. and Wood, R. A.

Guilyardi, E., Gualdi, S., Slingo, J., Navarra, A., Delecluse, P., Cole, J., Madec, G., Roberts, M., Latif, M. and Terray, L.

Inness, P. M., Slingo, J. M., Woolnough, S., Neale, R., and Pope, V.

Inness, P. M., Slingo, J. M., Guilyardi, E. and Cole, J.

Intergovernmental Panel on Climate Change

Johns, T. C., Gregory, J. M., Ingram, W. J., Johnson, C. E., Jones, A., Lowe, J. A., Mitchell, J. F. B.,

Roberts, D. L.,

Sexton, D. M. H.,

Stevenson, D. S., Tett, S. F. B. and Woodage M. J.

Ju, J. and Slingo, J. M.

Kim, K.-M. and Lau, K.-M.

\section{REFERENCES}

2003 Response of the Indian Monsoon and ENSO-monsoon teleconnections to enhanced greenhouse effect in the CNRM coupled model. J. Meteorol. Soc. Jpn., 81, 779-803

1981 'Predictability of monsoons'. Pp. 99-109 in Monsoon Dynamics. Eds. J. Lighthill and R. P. Pearce, Cambridge University Press, Cambridge, UK

2001 Influence of mean state changes on the structure of ENSO in a tropical coupled GCM. J. Climate, 14, 730-742

1998 Monsoon precipitation in the AMIP runs. Clim. Dyn., 14, 659689

2000 The simulation of SST, sea ice extents and ocean heat transports in a version of the Hadley Centre coupled model without flux adjustments. Clim. Dyn., 16, 147-168

2004 Representing El Niño in coupled ocean-atmosphere GCMs: the dominant role of the atmospheric component. J. Climate, 17, 4623-4629

2001 Organization of tropical convection in a GCM with varying vertical resolution: Implications for the simulation of the Madden-Julian Oscillation. Clim. Dyn., 17, 777-793

2003 Simulation of the Madden-Julian Oscillation in a coupled general circulation model. Part II: The role of the basic state. $\mathrm{J}$. Climate, 16, 365-382

2001 Climate change 2001: The scientific basis. Contribution of Working Group I to the Third Assessment Report, Eds. J. T. Houghton, Y. Ding, D. J. Griggs, M. Noguer, P. J. van der Linden, X. Dai, K. Maskell and C. A. Johnson, Cambridge University Press, UK

2003 Anthropogenic climate change for 1860 to 2100 simulated with the HadCM3 model under updated emission scenarios. Clim. Dyn., 20, 583-612
The Asian summer monsoon and ENSO. Q. J. R. Meteorol. Soc., 121, 1133-1168

Dynamics of monsoon-induced biennial variability in ENSO. Geophys. Res. Lett., 28, 315-318 
Latif, M., Sperber, K., Arblaster, J., 2001

Braconnot, P., Chen, D., Colman, A., Cubasch, U.,

Cooper, C., Delecluse, P.,

Dewitt, D., Fairhead, L.,

Flato, G., Hogan, T., Ji, M.,

Kimoto, M., Kitoh, A.,

Knutson, T., Le Treut, H.,

Li, T., Manabe, S., Marti, O.,

Mechoso, C., Meehl, G.,

Power, S., Roeckner, E.,

Sirven, J., Terray, L.,

Vintzileos, A., Voss, R.,

Wang, B., Washington, W.,

Yoshikawa, I., Yu, J. and

Zebiak, S.

Lau, K.-M. and Wu, H. T.

Lengaigne, M. E., Boulanger, J.-P., Menkes, C., Masson, S.,

Madec, G. and Delecluse, P.

Lengaigne, M. E., Guilyardi, E.,

Boulanger, J.-P., Menkes, C.,

Delecluse, P., Inness, P. M.,

Cole, J. and Slingo, J. M.

Levitus, S. and Boyer, T. P.

Meehl, G. A.

Meehl, G. A. and Arblaster, J. M.

Meehl, G. A., Gent, P. R.,

Arblaster, J. M.,

Otto-Bliesner, B. L.,

Brady, E. C. and Craig, A.

Meehl, G. A., Arblaster, J. M. and Loschnigg, J

Neale, R. and Slingo, J.

Normand, C.

Palmer, T. N.

Parthasarathy, B., Munot, A. A. and Kothawale, D. R.

Pope, V. D., Gallani, M. L.,

Rowntree, P. R. and

Stratton, R. A.

Rajeevan, M., Pai, D. S.,

Dikshit, S. K. and

Kelkar, R. R.

Rayner, N. A., Parker, D. E.,

Horton, E. B., Folland, C. K., Alexander, L. V.,

Rowell, D. P., Kent, E. C. and Kaplan, A.

Shukla, J. and Paolino, D.

Spencer, H., Slingo, J. M. and

Davey, M. K.

2002

2003

2004
ENSIP: the El Niño simulation intercomparison project. Clim. Dyn., 18, 255-276

2001 Principal Modes of Rainfall-SST Variability of the Asian Summer Monsoon: A Reassessment of the Monsoon-ENSO Relationship. J. Climate, 14, 2880-2895

Ocean response to the March 1997 Westerly Wind Event. J. Geophys. Res., 107(C12), 8015, doi: 10.1029/2001JC000841

2004 Triggering of El Niño by Westerly Wind Events in a Coupled General Circulation Model. Clim. Dyn., 23, 601-620, doi: 10.1007/s00382-004-0457-2

1994 'World Ocean Atlas 1994, Volume 4: Temperature'. US Department of Commerce, Washington, DC

1987 The annual cycle and interannual variability in the tropical Pacific and Indian Ocean regions. Mon. Weather Rev., 115, 27-50

2002a The Tropospheric Biennial Oscillation and Asian-Australian Monsoon Rainfall. J. Climate, 15, 722-744

2002b Indian Monsoon GCM Sensitivity Experiments Testing Tropospheric Biennial Oscillation Transition Conditions. J. Climate, 15, 923-944

2001 Factors that affect the amplitude of El Nino in global coupled climate models. Clim. Dyn., 17, 515-526

Coupled Ocean-Atmosphere Dynamical Processes in the Tropical Indian and Pacific Oceans and the TBO. J. Climate, 16, 2138-2158

2003 The Maritime Continent and its Role in the Global Climate: A GCM Study. J. Climate, 16, 834-848

1953 Monsoon seasonal forecasting. Q. J. R. Meteorol. Soc., 79, 463 473

1994 Chaos and predictability in forecasting the monsoons. Proc. Indian Natl. Sci. Acad., 60, 57-66

1994 All-India Monthly and Seasonal Rainfall Series: 1871-1993. Theor. Appl. Climatol., 49, 217-224

2000 The impact of new physical parametrizations in the Hadley Centre climate model: HadAM3. Clim. Dyn., 16, 123-146

IMD's new operational models for long-range forecast of southwest monsoon rainfall over India and their verification for 2003. Current Science, 86, 422-431

2003 Global analyses of sea surface temperature, sea ice, and night marine air temperature since the late nineteenth century. J. Geophys. Res., 108(D14), 4407, doi: 10.1029/2002JD002670

1983 The southern oscillation and long-range forecasting of the summer monsoon rainfall over India. Mon. Weather Rev., 111, $1830-1837$

2004 Seasonal predictability of ENSO teleconnections: the role of the remote ocean response. Clim. Dyn., 22, 511-526 
Spencer, H., Sutton, R.,

Slingo, J. M., Roberts, M. and Black, E.

Sperber, K. R. and Palmer, T. N.

Sperber, K. R., Slingo, J. M. and Annamalai, $\mathrm{H}$.

Webster, P. J. and Yang, S.

Webster, P. J., Magana, V. O., Palmer, T. N., Shukla, J., Tomas, R. A., Yanai, M. and Yasanuri, T.

Wu, R. and Kirtman, B. P.

Xie, P. and Arkin, P. A.
2005 Indian Ocean Climate and Dipole Variability in Hadley Centre Coupled GCMs. J. Climate, in press

1996 Interannual tropical rainfall variability in general circulation model simulations associated with the atmospheric model intercomparison project. J. Climate, 9, 2727-2750

2000 Predictability and the relationship between subseasonal and interannual variability during the Asian summer monsoon. Q. J. R. Meteorol. Soc., 126, 2545-2574

1992 Monsoon and ENSO: Selectively interactive systems. Q. J. R. Meteorol. Soc., 118, 877-926

1998 Monsoons: Processes, predictability, and prospects for prediction. J. Geophys. Res., 103, 14451-14510

2004 The Tropospheric Biennial Oscillation of the MonsoonENSO System in an Interactive Ensemble Coupled GCM. J. Climate, 17, 1623-1640

1997 Global precipitation: A 17-year monthly analysis based on gauge observations, satellite estimates, and numerical model outputs. Bull. Am. Meteorol. Soc., 78, 2539-2559 